Rubina Dad, MPhil

Susan Walker, PhD

Stephen W. Scherer, PhD

Muhammad Jawad

Hassan, PhD

Mohammad Domaia

Alghamdi, MD

Berge A. Minassian, MD

Reem A. Alkhater, MD,

FRCP (C), MSc

Neurol Genet

2017;3:e156; doi: 10.1212/ NXG.0000000000000156

Supplemental data at Neurology.org/ng

\section{FEBRILE ATAXIA AND MYOKYMIA BROADEN THE SPG26 HEREDITARY SPASTIC PARAPLEGIA PHENOTYPE \\ OPEN}

Hereditary spastic paraplegias (SPGs) are among the genetically most diverse neurologic disorders with over 70 loci identified. ${ }^{1,2}$ The recessively inherited SPG26 is caused by mutations in B4GALNT1, encoding the $\beta-1-4-\mathrm{N}$-acetyl-galactosaminyl transferase which functions in the biosynthesis of complex glycosphingolipids. To date, 12 families have been reported in 3 publications, with a broad phenotypic spectrum within and between families (table 1). We add a new family to the literature with 3 affected members and a remarkable phenotype of purely fever-induced ataxia with myokymia. We also review all published cases $^{3-5}$ to encapsulate the current knowledge of the neurologic features and spectrum of this disease.

Our proband presented at age 5 years with severe fever-induced ataxia and myokymia, the latter in the flexor muscles of the hands and feet, which additionally exhibited carpopedal spasm. Presumed postviral cerebellitis, he was treated with methylprednisolone and IV immunoglobulin and recovered fully in a week. He had 4 additional identical episodes until age 10 , all induced by a febrile illness $\left(39-40^{\circ} \mathrm{C}\right)$, each self-resolving, untreated, following defervescence. Examination at age 11 shows proximal muscle weakness, mild lower limb spasticity, preserved deep tendon reflexes and sensation, intact cognition, normal brain MRI, and evidence of peripheral neuropathy on nerve conduction study. His parents are first-degree cousins, and he has 2 older sisters and 1 older brother. The sisters are lean and tall with relative microcephaly, and on examination have reduced muscle bulk, proximal muscle weakness, and mildly spastic gait. The elder sister had had Achilles tendon release surgery at age 8 but continued to have lower limb spasticity. Her and affected brother's Spastic Paraplegia Rating Scale scores were 4/52 and 13/52, respectively (tables e-1 and e-2 at Neurology.org/ng). The older brother was and remains healthy. Wholeexome sequencing (e-Methods) for proband and 1 sister revealed a single significant shared homozygous variant, namely B4GALNT1 chr12:58021427:G>C;

Clinical/Scientific Notes

NM_001478: c.C1358G; p.Pro453Arg. No other known SPG, myokymia, or ataxia-related genes harbored clinically relevant variants (table e-3). Sanger sequencing in all family members confirmed that the B4GALNT1 change was homozygous in proband and sisters and heterozygous in healthy brother and parents. It was not present in the 1000 Genomes European, American, Asian, or African databases, dbSNP or ExAC. The variant was predicted damaging by PolyPhen 2 and CADD and evolutionarily conserved (PhyloP). No further functional consequences could be predicted.

A summary of all SPG26 published cases (table 1) reveals spastic paraparesis as a commonly shared core symptom. The disease extends to other systems and includes dysarthria, ataxia, intellectual disability, and psychiatric manifestations, none of which is uniformly present across families and even within families. Onset is in childhood, usually before age 10 , in all families except 1 , with a missense mutation and onset between 28 and 39 years. In this family, despite late onset, progression was rapid, with severe muscle wasting. ${ }^{3}$ Our family, with another missense mutation, appears to be the mildest to date among childhood-onset cases, and the phenotype is particularly mild in the 2 girls (table 1). They had a later age at onset than the boy (8 vs 5), and, despite being older (15 and 21 vs 11 ), have no muscle wasting or ataxia and only mild spasticity. Finally, the male patient manifests a symptom set not previously reported, namely febrile ataxia and myokymia with full recovery after each attack.

Complex glycosphingolipids (e.g., GM1 or GD1a gangliosides) are crucial components of plasma membranes but are by far most abundant in nervous tissue. Their 2 principal roles are to mediate cell-cell interactions and regulate membrane protein functions. Additional functions include endocytosis, signal transduction, and synaptic plasticity. Complex glycosphingolipids represent a family of many molecules, the shared "glyco" component consisting of 4 glucans serially added to the sphingolipid during biosynthesis. B4GALNT1 catalyzes the addition of the third ( $\mathrm{N}$-acetyl- $\beta$-D-galactosamine) to the second glucan, and the absence of the enzyme results in nonprogression to the more complex forms (e.g., from GM3 to GM2 and GM1). ${ }^{6}$ B 4 galnt1 knockout mice 


\begin{tabular}{|c|c|c|c|c|c|c|c|c|c|c|c|c|c|c|}
\hline \multirow{3}{*}{$\begin{array}{l}\text { Table } 1 \\
\text { Families }\end{array}$} & \multicolumn{14}{|c|}{ Summary of clinical features of all published cases with B4GALNT1 mutations (NM_001478) } \\
\hline & \multicolumn{2}{|c|}{ Present study } & \multicolumn{2}{|c|}{ Reference 5} & \multicolumn{7}{|l|}{ Reference 4} & \multicolumn{3}{|l|}{ Reference 3} \\
\hline & Saudi & & Bedouin & Bedouin & Spanish & Tunisian & Brazilian & Algerian & Portuguese & French & German & Kuwaiti & Italian & Amish \\
\hline Affected & 2 girls & 1 boy & 4 & 5 & 3 & 4 & 5 & 1 & 4 & 1 & 3 & 5 & 2 & 4 \\
\hline $\begin{array}{l}\text { Age at } \\
\text { onset, } y\end{array}$ & 8 & 5 & $\begin{array}{l}\text { Early } \\
\text { childhood }\end{array}$ & $6-7$ & $7-8$ & $3-19$ & $9-14$ & 11 & $2-3$ & Early & Early & $6-11$ & $28-39$ & $\begin{array}{l}\text { Second year } \\
\text { of life }\end{array}$ \\
\hline Dysarthria & No & Mild & Severe & Severe & NS & 1 yes, 3 no & No & No & Mild & Mod & No-sev & No-sev & NS & NS \\
\hline Spasticity & Mild & Mod & Severe & Severe & Yes, NOS & Mod-sev & Mod-sev & Mod & Mild-mod & Severe & Mod-sev & Mod & Mod-sev & Mod \\
\hline Ataxia & No & Febrile & Severe & Severe & Yes & No & Mild & Moderate & Mild-mod & Severe & No & Severe & Mod-sev & Mod-sev \\
\hline Reflexes & Normal & Normal & $\downarrow$ & $\downarrow$ & Brisk & Brisk & Brisk & Brisk & $\downarrow$ & NS & Normal & $\downarrow$ & $\downarrow$ & $\downarrow$ \\
\hline $\begin{array}{l}\text { Muscle } \\
\text { wasting }\end{array}$ & No & No & Severe & Severe & Moderate & No-sev & No & No & Mild-sev & Severe & Mod-sev & Severe & Severe & Mild-mod \\
\hline Other & & & & & Cataract & & Dysmorphism & & & & & & & Seizure \\
\hline $\begin{array}{l}\text { Behavior } \\
\text { and } \\
\text { cognition }\end{array}$ & Normal & Normal & $\begin{array}{l}\text { Autism, } \\
\text { mod-sev } \\
\text { ID }\end{array}$ & $\begin{array}{l}\text { Emotional } \\
\text { lability, mild } \\
\text { ID }\end{array}$ & Mild-mod ID & Mild-mod ID & Mild-mod ID & Mild-mod ID & Mild-mod ID & Mild-mod ID & Mild-mod ID & $\begin{array}{l}\text { Emotional } \\
\text { lability, } \\
\text { severe ID }\end{array}$ & $\begin{array}{l}\text { Mild- } \\
\text { severe ID }\end{array}$ & $\begin{array}{l}\text { Autism, } \\
\text { mild-mod ID }\end{array}$ \\
\hline $\begin{array}{l}\text { Brain or } \\
\text { spinal MRI }\end{array}$ & Normal & Normal & Normal & Normal & $\begin{array}{l}\text { Cerebral } \\
\text { atrophy }\end{array}$ & $\begin{array}{l}\text { Normal in 1, } \\
\text { ND in } 3\end{array}$ & Normal & $\begin{array}{l}\text { Cerebral } \\
\text { atrophy }\end{array}$ & $\begin{array}{l}\text { Subcortical } \\
\text { periventricular } \\
\text { WMH }\end{array}$ & Cerebral atrophy & Normal (CT) & Normal & $\begin{array}{l}\text { Congenital } \\
\text { spinal } \\
\text { stenosis }\end{array}$ & ND \\
\hline NCS/EMG & Normal & $\begin{array}{l}\text { Axonal } \\
\text { neuropathy }\end{array}$ & ND & ND & $\begin{array}{l}\text { Axonal } \\
\text { neuropathy; } \\
\text { pes cavus }\end{array}$ & $\begin{array}{l}\text { Normal in 1, } \\
\text { ND in } 3\end{array}$ & Normal & $\begin{array}{l}\text { Axonal } \\
\text { neuropathy }\end{array}$ & $\begin{array}{l}\text { Pes cavus and } \\
\text { clinical } \\
\text { peripheral } \\
\text { neuropathy }\end{array}$ & Axonal neuropathy & $\begin{array}{l}\text { Axonal } \\
\text { neuropathy }\end{array}$ & Normal & $\begin{array}{l}\text { Decreased } \\
\text { sensory } \\
\text { amplitudes }\end{array}$ & $\begin{array}{l}\text { Pes cavus } \\
\text { and clinical } \\
\text { peripheral } \\
\text { neuropathy }\end{array}$ \\
\hline Mutations & \multicolumn{2}{|c|}{$\begin{array}{l}\text { c.C1358G; } \\
\text { p.Pro453Arg }\end{array}$} & $\begin{array}{l}\text { c. } 1003- \\
2 A>G\end{array}$ & $\begin{array}{l}\text { c.1458_1459 } \\
\text { insA; } p \text {. } \\
\text { Leu487*fs }\end{array}$ & $\begin{array}{l}\text { c.395delC; p. } \\
\text { Pro132Glnfs*7 }\end{array}$ & $\begin{array}{l}\text { c.898C }>T_{;} \\
\text {p.Arg300Cys }\end{array}$ & $\begin{array}{l}\text { c. } 682 \mathrm{C}>\mathrm{T} ; \mathrm{p} . \\
\text { Arg228* }\end{array}$ & $\begin{array}{l}\text { c.263 dupG; } \\
\text { p.Leu89fs*13 }\end{array}$ & $\begin{array}{l}\text { c. } 358 \mathrm{C}>\mathrm{T} ; \\
\text { p.Gln120* }\end{array}$ & $\begin{array}{l}\text { c.917_922dup; p.Thr } \\
\text { 307_Val308dup; } \\
\text { c.1315_1317delTTC; } \\
\text { p.Phe 439del }\end{array}$ & $\begin{array}{l}\text { c.1298A>C; } \\
\text { p.Asp433Ala }\end{array}$ & $\begin{array}{l}\text { c.1458 } \\
\text { dup; } p \text {. } \\
\text { Leu487Thr } \\
\text { fs*77 }\end{array}$ & $\begin{array}{l}\text { c.852 } \\
\text { G }>\text { C; p. } \\
\text { Lys284Asn }\end{array}$ & $\begin{array}{l}\text { c. } 1514 \\
G>A ; p . \\
\text { Arg505His }\end{array}$ \\
\hline
\end{tabular}

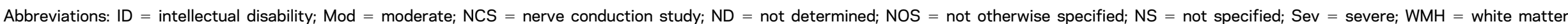
hyperintensity.

The downward arrow indicates decreased deep tendon reflex. 
are healthy, suggesting that shorter gangliosides (e.g., GM3) largely compensate for absent longer forms. ${ }^{7}$ This appears to be the case also in humans, as evidenced by the patients discussed here, but only for the years until disease onset. After that, there is progressive neurologic decompensation. Precisely, which complex ganglioside deficiency(ies) in which cell types, regions or pathways underlie the upper and lower motor neuron disease and other aspects of SPG26 await future studies. This knowledge will help elucidate the roles of complex glycosphingolipids in the development and function of the central and peripheral nervous systems.

From the Atta-ur Rahman School of Applied Biosciences (R.D., M.J. H.), National University of Sciences and Technology (NUST), Pakistan; Program in Genetics and Genome Biology (R.D., B.A.M.), Division of Neurology (B.A.M.), Department of Paediatrics, and The Centre for Applied Genomics, Genetics and Genome Biology (S.W., S.W.S.), The Hospital for Sick Children; Department of Molecular Genetics (S.W.S.), and McLaughlin Centre (S.W.S.), University of Toronto, Ontario, Canada; and Department of Pediatrics (M.D.A., R.A.A.), Division of Neurology, Johns Hopkins Aramco Healthcare, Dhahran, Saudi Arabia.

Author contributions: Study concept and design by Berge A. Minassian and Reem A. Alkhater. Acquisition of clinical data by Reem A. Alkhater and Mohammad Domaia Alghamdi. Acquisition of data by Susan Walker and Stephen W. Scherer. Analysis and interpretation of data by Rubina Dad and Susan Walker. Study supervision by Berge A. Minassian, Reem A. Alkhater, and Muhammad Jawad Hassan. Critical revision of manuscript for intellectual content, coinvestigators: Berge A. Minassian, Reem A. Alkhater, and Mohammad Domaia Alghamdi.

Acknowledgment: The authors thank the family members for participation in the study. Rubina Dad acknowledges her funding by the Higher Education Commission of Pakistan under the International Research Support Initiative Program (HEC-IRSIP).

Study funding: No targeted funding reported.

Disclosure: Rubina Dad, Susan Walker, Muhammad Jawad Hassan, Mohammad Domaia Alghamdi, and Reem A. Alkhater report no disclosures. Stephen Scherer has served on the scientific advisory board of Population Diagnostics; has served on the editorial boards of Genomic Medicine, Genes, Genomes, Genetics, Journal of Personalized Medicine, The Open Genomics Journal, The Hugo
Journal, Genome Medicine, the Journal of Neurodevelopmental Disorders, Autism Research, PathoGenetics, Comparative and Functional Genomics, BMC Medical Genomics, and Cytogenetics and Genome Research; and has received research support from Genome Canada/Ontario Genomics Institute, Canadian Institutes of Health Research, Canadian Institute for Advanced Research, McLaughlin Centre, Canada Foundation for Innovation, government of Ontario, NIH, Autism Speaks, and SickKids Foundation. Berge A. Minassian holds patents for diagnostic testing of the following genes: $E P M 2 A, E P M 2 B, M E C P 2$, and VMA21; receives license fee payments/royalty payments for aforementioned patents; and has received research support from National Institute of Neurological Disorders and Stroke of the NIH. Go to Neurology.org/ng for full disclosure forms. The Article Processing Charge was funded by the authors.

This is an open access article distributed under the terms of the Creative Commons Attribution-NonCommercial-NoDerivatives L $i$ cense 4.0 (CC BY-NC-ND), which permits downloading and sharing the work provided it is properly cited. The work cannot be changed in any way or used commercially without permission from the journal.

Received December 2, 2016. Accepted in final form April 13, 2017.

Correspondence to Dr. Alkhater: Reem.khater@jhah.com

1. Noreau A, Dion PA, Rouleau GS. Molecular aspects of hereditary spastic paraplegias. Exp Cell Res 2014;325: $18-26$.

2. Chrestian N, Dupré N, Gan-Or Z, et al. Clinical and genetic study of hereditary spastic paraplegia in Canada. Neurol Genet 2016;3:e122. doi: 10.1212/NXG.0000000000000122.

3. Harlalka GV, Lehman A, Chioza B, et al. Mutations in B4GALNT1 (GM2 synthase) underlie a new disorder of ganglioside biosynthesis. Brain 2013;136:3618-3624.

4. Boukhris A, Schule R, Loureiro JL, et al. Alteration of ganglioside biosynthesis responsible for complex hereditary spastic paraplegia. Am J Hum Genet 2013;93:118-123.

5. Wakil S, Monies D, Ramzan K, et al. Novel B4GALNT1 mutations in a complicated form of hereditary spastic paraplegia. Clin Genet 2014;86:500-501.

6. Schnaar RL. Brain gangliosides in axon-myelin stability and axon regeneration. FEBS Lett 2010;584:1741-1747.

7. Takamiya K, Yamamoto A, Furukawa K, et al. Mice with disrupted GM2/GD2 synthase gene lack complex gangliosides but exhibit only subtle defects in their nervous system. Proc Natl Acad Sci USA 1996;93: 10662-10667. 


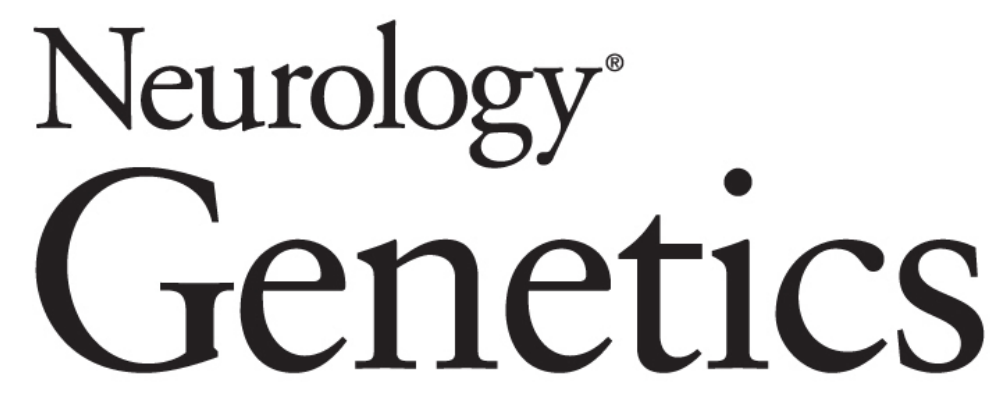

Febrile ataxia and myokymia broaden the SPG26 hereditary spastic paraplegia phenotype

Rubina Dad, Susan Walker, Stephen W. Scherer, et al. Neurol Genet 2017;3;

DOI 10.1212/NXG.0000000000000156

This information is current as of May 23, 2017

Neurol Genet is an official journal of the American Academy of Neurology. Published since April 2015, it is an open-access, online-only, continuous publication journal. Copyright Copyright $(2017$ The Author(s). Published by Wolters Kluwer Health, Inc. on behalf of the American Academy of Neurology.. All rights reserved. Online ISSN: 2376-7839.

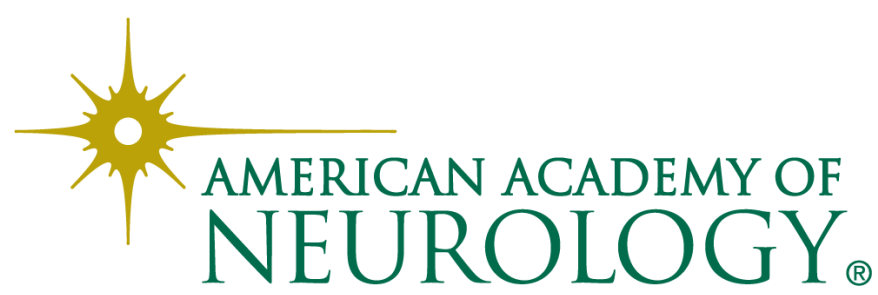




\section{Updated Information \& Services}

\section{Supplementary Material}

References

Subspecialty Collections

Permissions \& Licensing

Reprints including high resolution figures, can be found at: http://ng.neurology.org/content/3/3/e156.full.html

Supplementary material can be found at: http://ng.neurology.org/content/suppl/2017/05/23/3.3.e156.DC1

This article cites 7 articles, 1 of which you can access for free at: http://ng.neurology.org/content/3/3/e156.full.html\#\#ref-list-1

This article, along with others on similar topics, appears in the following collection(s):

\section{All Genetics}

http://ng.neurology.org//cgi/collection/all_genetics

All Neuromuscular Disease

http://ng.neurology.org//cgi/collection/all_neuromuscular_disease

Gait disorders/ataxia

http://ng.neurology.org//cgi/collection/gait_disorders_ataxia

\section{MRI}

http://ng.neurology.org//cgi/collection/mri

Spastic paraplegia

http://ng.neurology.org//cgi/collection/spastic_paraplegia

Information about reproducing this article in parts (figures,tables) or in its entirety can be found online at:

http://ng.neurology.org/misc/about.xhtml\#permissions

Information about ordering reprints can be found online: http://ng.neurology.org/misc/addir.xhtml\#reprintsus

Neurol Genet is an official journal of the American Academy of Neurology. Published since April 2015, it is an open-access, online-only, continuous publication journal. Copyright Copyright $\odot 2017$ The Author(s). Published by Wolters Kluwer Health, Inc. on behalf of the American Academy of Neurology.. All rights reserved. Online ISSN: 2376-7839.

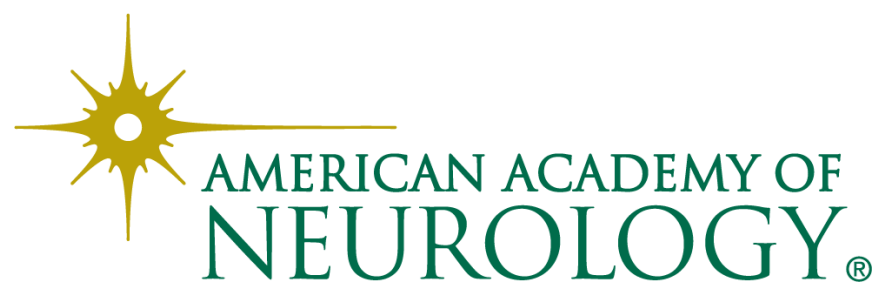

